\title{
Rethinking Ajaran Zakat
}

Taufikur Rahman

STAIN Salatiga

E-mail: Takur067782@yahoo.co.id

Judul : Pajak Itu Zakat: Uang Allah Untuk Kemaslahatan Rakyat

Penulis : Masdar Farid Mas'udi

Cetakan : 1, Agustus 2010

Penerbit : PT Mizan Pustaka

Tebal : 236 halaman

\section{Pendahuluan}

Salah satu kajian yang cukup diminati oleh umat sampai saat ini adalah kajian tentang zakat. Banyak buku, penelitian, media massa, dialog, diskusi, workshop dan seminar yang telah membahas tema tentang seputar ajaran zakat. Tema zakat ini menarik untuk dibahas karena zakat merupakan bentuk ibadah yang tidak hanya sekedar bersifat individual/personal, melainkan juga bercorak kemasyarakatan. Artinya, di dalam ajaran zakat, pandangan dan komitmen sosialnya cukup jelas, bahkan dari titik kepentingan yang menyentuh hajat orang banyak, yaitu pemenuhan kebutuhan ekonomi. Ajaran zakat juga menyentuh langsung dengan realitas kehidupan manusia yang nyata atau realitas sosial yang terus berkembang dan berubah dari waktu ke waktu. Sehingga, zakat sering disebut juga dengan ibadah māliyah ijtima'iyah, yaitu ibadah kebendaan yang bertujuan kemasyarakatan. Saking pentingnya zakat ini, hingga Rasulullah menganjurkan pemungutannya secara paksa. Bahkan pada masa khalifah Abu Bakar Al-Siddiq, beliau pernah menyatakan perang suci terhadap orang-orang yang tidak membayar zakat (Anshari, 2006: iv). Di dalam perekonomian Islam terdapat dua persoalan penting yang perlu sekali dipelajari dan dikaji sampai tuntas dari segenap segi. Pertama adalah zakat, sedangkan yang kedua adalah riba (AlQarḍ̄âi, 1991: 5). 
Zakat merupakan salah satu cara untuk mewujudkan keseimbangan keadilan sosial di dunia dengan cara tolong-menolong, yang kaya memberi bantuan kepada yang miskin, yang kuat memberi pertolongan kepada yang lemah (Sari, 2007: 3). Zakat adalah salah satu instrumen penting di dalam Islam dalam mensejahterakan umat. Apabila zakat dikelola dengan baik dan penyalurannya merata, akan menimbulkan kesejahteraan tidak saja pada individu, tapi juga pada umat dan negara. Oleh karena itu, jika substansi ini benar-benar diterapkan di Indonesia maka tentunya tidak akan terjadi ketimpangan sosial yang begitu dalam antara si kaya dan si miskin. Dengan zakat, maka akan terwujud keseimbangan taraf hidup di antara anggota masyarakat (Hafidhuddin, 2007: x). Hasil pengumpulan zakat merupakan sumber dana yang potensial bagi upaya mewujudkan kesejahteraan masyarakat. Sehingga dapat dikatakan bahwa zakat merupakan pranata keagamaan untuk mewujudkan keadilan sosial bagi seluruh rakyat Indonesia dengan memperhatikan masyarakat yang kurang mampu (Anshari, 2006: 165). Dengan demikian, zakat adalah salah satu cara utama untuk mencapai masyarakat yang bahagia, adil dan makmur, karena dengan memberikan sebagian dari kekayaan si hartawan kepada fakir miskin, dapat dijadikan sebagai modal untuk melakukan sesuatu usaha (Siddik, 1993: 32).

Menurut Monzer Kahf, tujuan utama dari zakat adalah untuk mencapai keadilan sosial ekonomi. Zakat merupakan transfer sederhana dari sebagian harta dengan ukuran tertentu milik si kaya untuk dialokasikan kepada si miskin (Kahf, 1999). Zakat berhubungan dengan prinsip keadilan. Keadilan bersifat primer. Masalah paling mendasar adalah masalah keadilan ekonomi, bagaimana orang yang tidak memperoleh rezeki, dapat ikut merasakan rezeki. Oleh karena itu, dalam rangka mengentaskan kemiskinan, harus ada usaha yang secara sungguh-sungguh merupakan tanggung-jawab untuk menegakkan keadilan yang kita mulai dari keadilan ekonomi (Mas'udi dalam Rahmat, 2003: 100).

Dari beberapa uraian di atas, tedapat satu visi penting yang terdapat di dalam ajaran zakat, yakni menegakkan keadilan sosial dan kemaslahatan rakyat banyak dalam kehidupan sosialnya, terutama yang lemah dan tidak berdaya. Sehingga, apabila zakat ini dikelola dengan baik dan benar, maka tidak ada ketimpangan hidup dan ketidakadilan sosial antara yang mampu dan yang tidak mampu. 
Dalam rangka merealisasikan visi penting bangunan sosial Islam tersebut, maka penulis buku ini mencoba memberikan pemikiran dan penafsiran ulang tentang ajaran zakat. Dari beberapa konsep tentang zakat dan sistem zakat yang ada, selama ini masih belum mampu melihat akar permasalahan yang sebenarnya, atau dengan kata lain, tidak langsung kepada jantung permasalahannya. Salah satu sebabnya adalah karena cara pandang yang digunakan dalam konsep zakat dan sistem zakat yang ada selama ini adalah pandangan keagamaan yang formalistik bukan substantivistik, artinya selama ini zakat dipandang hanya sebagai amaliah ritualitas dan bersifat seremonial belaka. Zakat dipandang sebagai ibadah yang hanya berdimensi personal dan individual, sama sekali tidak bersentuhan dengan dimensi sosial, sehingga zakat tidak berdampak sosial apa pun. Begitu juga dalam memahami dan mengkaji konsep dan sistem zakat cenderung lebih bersifat tekstual dan literal bukan secara kontekstual dan rasional. Sementara itu, realitas sosial yang terjadi di masyarakat dari waktu ke waktu selalu mengalami perubahan dan perkembangan seperti di era sekarang ini. Permasalahan yang muncul pun juga mengalami perkembangan yang lebih beragam dan kompleks, tak terkecuali berkaitan dengan permasalahan seputar zakat sebagai salah satu instrumen untuk menegakkan keadilan sosial dan kemaslahatan umat. Persoalan-persoalan yang muncul di masa sekarang ini, mungkin belum dikenal oleh para ahli fikih pada masa lalu maupun belakangan ini (Al-Qarḍāwi, 1991: 7). Tulisan dan pendekatan yang mereka gunakan hanya cocok untuk zaman mereka, tetapi belum tentu cocok jika dipakai untuk zaman sekarang.

Oleh karena itu, Masdar F Mas'udi dalam bukunya ingin mencoba menawarkan sebuah pemikiran tentang konsep zakat dan sistem zakat yang dirasa mampu menjawab tuntutan persoalan-persoalan realitas umat yang cenderung berubah di zaman modern ini, terutama berhubungan dengan zakat sebagai instrumen merealisasikan keadilan sosial dan kesejahteraan umat. Substansi permasalahan zakat yang sebenarnya terjadi selama ini adalah terletak pada pertama, segi filosofisnya. Kedua, segi struktur dan kelembagaannya. Ketiga, segi manajemen operasionalnya. Menurut Mas'udi, konsep zakat dalam Islam adalah konsep perpajakan. Islam perlu mengintervensi seluruh lembaga perpajakan yang ada (Mas'udi dalam Rahmat, 2003: 101). Mas'udi ingin mencoba meyakinkan bahwa sebagai bagian dari ajaran agama 
untuk kehidupan sosial, zakat pada dasarnya adalah konsep etik atau moral, sementara wujud institusional atau kelembagaanya adalah pajak dan pengelolaan serta pembelanjaannya ada dalam kewenangan negara.

Seperti halnya ruh dan badan. Zakat adalah ruh, sedangkan pajak adalah badannya. Oleh sebab itu, barang siapa dari umat beriman yang telah membayarkan pajaknya, dengan niat zakat, kepada negara/pemerintah, maka terpenuhilah sudah kewajiban agamanya. Sebagai seorang muslim, ia telah menunaikan tanggung-jawab sosialnya secara benar dan semestinya. Sebaliknya, seberapapun besarnya sumbangan atau infak seorang muslim kepada pihak-pihak tertentu tanpa lewat negara/pemerintah, maka sumbangan itu hanya dianggap sebagai sedekah biasa (tatawwu') yang bersifat ekstra (nāfilah) dan tidak bisa menggugurkan kewajiban pajak (sedekah zakat)nya (Mas'udi, 2010: xx). Buku ini ditulis dengan titik tolak bertambah parahnya problem keadilan sosial khususnya bagi yang lemah dan terpinggirkan sebagai mandat negara yang seharusnya tertuang secara nyata dan terukur dalam kebijakannya yang paling strategis, yaitu kebijakan anggaran.

\section{Tentang Penulis}

Masdar Farid Mas'udi lahir di dusun Jombor, Cipete, Cilongok, Purwokerto pada tahun 1954. Dia pernah kuliah di S-2 program filsafat UI (1996), Fakultas Syariah IAIN Sunan Kalijaga Yogyakarta (1979) Jurusan Tafsir-Hadist. Mas'udi pernah berguru (nyantri) kepada Kiai Ali Maksoem Krapyak Yogyakarta (1968-1974) dan kepada Kiai Khudlori di Pesantren Tegalrejo, Magelang (1966-1968).

Pengalaman organisasi Masdar F Mas'udi diawali ketika tahun 1972 dipilih sebagai ketua Pergerakan Mahasiswa Islam Indonesia (PMII) Komisariat Krapyak, Yogyakarta, sampai dengan 1974. Selanjutnya pada tahun 1976 terpilih sebagai Sekjen Dewan Mahasiswa IAIN Sunan Kalijaga Yogyakarta sampai dengan 1978. Tahun 1982, setelah hijrah di Jakarta, Mas'udi dipilih sebagai Ketua I Pengurus Besar PMII periode 1982 - 1987 mendampingi Muhyidin Arubusman sebagai Ketua Umum. Selesai kuliah, tahun 1980 Mas'udi hijrah ke Jakarta dan bekerja untuk Lembaga Missi Islam NU sambil menjadi wartawan di beberapa media masa ibu kota. Tahun 
1985, sehabis muktamar Situbondo, bersama dengan K. Irfan Zidni, Mas'udi ditunjuk sebagai asisten Ketua Umum (Gus Dur) dan Rais 'Am di bidang Pengembangan Pemikiran Keagamaan. Sebagai koordinator program P3M (Perhimpunan Pengembangan Pesantren dan Masyarakat), Mas'udi sempat menerbitkan Jurnal PESANTREN, yang pertama dan satu-satunya jurnal ilmiah Islam yang terbit antara tahun 1984 - 1990.

Dimulai dari halaqah Watucongol tahun 1989 dengan tema "Memahami Kitab Kuning secara Kontekstual", kegiatan itu terus bergulir di berbagai daerah dengan keikut sertaan para kyai, baik yang sepuh maupun yang muda. Salah satu diantara output-nya yang monumental adalah rumusan Metode Pengambilan Hukum yang menjadi keputusan Munas NU Lampung 1992. Pada tahun 2004, Masdar Farid Mas'udi terpilih sebagai Ketua Pengurus Besar Nahdlatul Ulama setelah sebelumnya selama tiga bulan ditunjuk Majelis Syuriah sebagai Pelaksana Harian Umum PBNU. Beliau pernah juga menjabat sebagai Sekretaris Majelis Syuriah PBNU (1999-2004), di samping sebagai ketua P3M (Perhimpunan Pengembangan Pesantren dan Masyarakat (2000), anggota Komisi Ombudsman Nasional (2000) dan Dewan Etik Indonesian Corruption Watch (2003). Di tengah kesibukannya, ia masih membina pesantren Al-Bayan, di kampung Cikiwul, Pancoran Mas, Cibadak, Sukabumi.

\section{Letak Ajaran Zakat Dalam Islam}

Islam merupakan agama yang rahmatan lil 'ālamin atau rahmat bagi semesta alam (QS. Al-Anbiya': 107). Berdasarkan ayat tersebut, beberapa ulama berpendapat bahwa agama Islam adalah agama yang menunjukkan komitmennya terhadap hal-hal yang menjadi kepentingan semua pihak, semua golongan, bahkan semua makhluk yang ada di alam semesta ini, tanpa membedakan warna kulit, bahasa, budaya, dan keyakinan masing-masing. Artinya bahwa Islam adalah agama universal. Misi dan kebenaran ajaran Islam melampaui batas-batas suku, etnis, bangsa, dan bahasa. Lebih dari itu, Islam juga diyakini sebagai agama penutup, sehingga secara intrinsik, jangkauan dakwah Islam mestilah mendunia, bukannya terbatasi pada agama, suku, rasial dan parokial, sebagaimana agama-agama terdahulu yang hanya dialamatkan pada suatu kaum tertentu (Taher, 2002: 39 ). 
Nilai-nilai universal Islam dapat menembus ruang dan waktu. Pesanpesan suci ajaran Islam bukan hanya terbatas untuk masyarakat Arab, dan juga tidak terbatas pada mereka yang sudah beriman. Akan tetapi sebaliknya, ajakan suci juga diserukan kepada semua umat manusia tanpa mengenal penyekatan dalam bentuk apapun (Yasid, 2004: 35). Ajaran Islam tentang kasih sayang sesama manusia, perdamaian dunia, persaudaraan, dan persatuan sesama muslim, kerukunan antarumat beragama, pemeliharaan, pemakmuran, dan pembudidayaan bumi dan kekayaan di dalamnya, serta sikap adil dan tidak aniaya terhadap makhluk lain adalah bukti kongkrit misi rahmatan lil 'ālamīn (Tim Sembilan, 2004: 147). Status Islam sebagai ajaran yang universal, yang dapat dilaksanakan untuk melindungi kehidupan manusia secara menyeluruh tanpa harus terganggu oleh sekat-sekat regional, hanya mungkin dipertahankan bila ia dapat kita pahami sebagai ajaran yang justru bersifat terbuka. Dalam konteks Indonesia, berarti ia harus mampu menunjukkan sikap toleran, sebagai bentuk paling arif dalam menghadapi kenyataan kemajemukan bangsa Indonesia, yang rasanya tidak mungkin disikapi selain sebagai sunnatullah (Mahfudh, 1994: xlix)

Akan tetapi, karena pandangan keagamaan formalistis yang telah terlalu mendominasi pola pemahaman kita tentang "Islam", membuat sifat keuniversalan yang melekat pada Islam tersebut menjadi terdistorsi. Dalam hal ini agama lebih dihayati sebagai identitas formal saja, agama hanya sekedar formalitas serta hal-hal yang bersifat ritual. Dalam pandangan formalistis seperti ini, dengan sendirinya, tidak ada satu agama yang benar-benar berkapasitas universal, termasuk Islam yang berikrar menjadi rahmatan lil'ālamin (rahmat bagi semesta alam) pun ikut menjadi agama komunal, sejenis primordialisme kesukuan, yang hanya bisa diakrabi oleh dan hanya mengakrabi kepentingan komunitas yang mengafiliasikan diri dengannya. Sementara itu, pemikiran tentang bagaimana mewujudkan tatanan masyarakat yang adil hampir tidak pernah menarik perhatian. Atau, kalau ada yang tertarik, atas dasar "berlomba dalam kebaikan" (fastabiqu al-khairāt) yang juga dipahami secara formalistis, hal itu dilakukan semata-mata demi kepentingan kelompok dengan penyangkalan keras atas kepentingan yang sama dari pihak lainnya karena perbedaan keyakinan/paham. 
Menurut Nurcholis Madjid, kesalehan pribadi (personal piety) itu harus diwujudkan juga ke dalam kesalehan sosial (social piety). Kesalehan personal-individual saja tidak cukup, untuk menciptakan masyarakat etik. Setiap muslim harus menerapkan kesalehan sosial (Azra, 2007: 148). Konsep zakat merupakan salah satu upaya untuk menegakkan kesalehan sosial tersebut. Zakat merupakan sarana efektif menuju kesalehan sosial dengan menjadikan wahana pemberdayaan ekonomi kerakyatan, bukan sekedar ibadah yang sepi dari kepedulian sosial (Asmani, 2010: 93). Zakat adalah pintu masuk bagi umat Islam untuk memenuhi amanat kekhalifahannya dengan menegakkan keadilan dalam kehidupan sosialnya (Mas'udi, 2010: xvii).

Zakat adalah satu rukun yang bercorak sosial-ekonomi dari lima rukun Islam. Dengan zakat, di samping ikrar tauhid (syahadat) dan shalat, seseorang barulah sah masuk ke dalam barisan umat Islam dan diakui keislamannya (Al-Qarḍāwi, 1991: 3). Dalam Alquran ada dua perintah yang selalu dikemukakan secara bergandengan yaitu shalat dan zakat. Hal ini menunjukkan bahwa setelah mewajibkan umatnya untuk menunaikan perintah shalat sebagai bentuk ibadah ritual yang dimensi spiritualitasnya bersifat personal, maka selalu diikuti dengan kewajiban untuk membayar zakat sebagai bentuk ibadah yang berdimensi sosial (seluruh umat manusia) yang tidak mengenal sekat-sekat (suku, agama, bangsa, ras dan lainnya). Artinya, pembagian zakat tidak hanya diperuntukkan hanya bagi yang Muslim saja, melainkan juga diperuntukkan bagi mereka yang non Muslim. Apabila zakat hanya diberikan kepada umat Islam saja, maka akan bertentangan dengan misi Islam itu sendiri yakni rahmat bagi semesta alam (Mas'udi, 2010: 204). Inti ajaran zakat yang mutlak, universal, dan tidak berubah adalah: 1) siapa pun yang memiliki kelebihan harta harus menginfakkan sebagian yang diterimanya itu; 2) harta (rezeki) yang diinfakkan oleh atau dipungut dari yang mampu itu harus di-tasharruf-kan untuk kemaslahatan seluruh anggota masyarakat, dengan memprioritaskan mereka yang lemah (Mas'udi, 1992: 70-71). Dalam hadis Nabi saw, kedua perintah itu (shalat dan zakat) diletakkan sebagai rukun Islam segera setelah pengakuan terhadap keesaan Tuhan. Baru setelah itu, rukun-rukun yang lainnnya yaitu puasa dan haji. Khalifah Abu Bakar menyatakan bahwa ia tidak dapat sama sekali menerima pemisahan antara ibadah jasmaniah (shalat) dari ibadah kekayaan (zakat) (Al-Qarḍāwi, 1991: 82). 


\section{Distorsi Pemahaman Ajaran dan Praktik Zakat}

Tugas maha berat yang harus diemban manusia di muka bumi adalah sebagai khalifah (pemimpin), baik untuk dirinya sendiri maupun lingkungan alam. Tugas sebagai pemimpin itu secara umum adalah mewujudkan kemakmuran dan kesejahteraan dalam hidup dan kehidupan, melakukan tugas pengabdian serta melaksanakan ibadah dalam arti luas (Anshari, 2006: 1).

Akan tetapi, dalam rentang sejarahnya yang sangat panjang -lebih dari 12 abad- umat Islam telah mengabaikan amanat sosial kekhalifahannya yang notabene begitu jelas dalam ajaran agamanya tersebut. Islam yang komitmen sosialnya begitu eksplisit melalui zakat, telah menjadi agama yang hanya berurusan dengan kehidupan yang yang berskala personal-individual dan bersifat ritual saja. Hal itu membuat ajaran zakat menjadi terasingkan dari pesan-pesan utamanya. Zakat yang pada mulanya merupakan suatu visi "gerakan sosial" dengan jangkauan yang menyentuh realitas sosiostruktural, teredusir hanya menjadi aksi simbolik-personal yang tidak berdampak pada realitas sosial. Hal ini terjadi karena adanya pandangan keagamaan yang formalistis, verbal-tekstual, dan perilaku keagamaan yang feodalistis dalam diri umat Islam dalam memahami ajaran zakat dan memfungsikannya dalam kehidupan keberagamaan mereka.

Karena pandangan fikih yang sangat formalistik itulah dalam konteks sosial yang ada, ajaran syari'at yang tertuang dalam fikih terkadang terlihat tidak searah dengan bentuk kehidupan praktis sehari-hari. Zakat yang sebenarnya merupakan ajaran Islam yang semangatnya untuk menciptakan keadilan sosial ekonomi, dalam fikih sering dipahami sebagai ibadah formal yang hanya menjelaskan kewajiban muzaki untuk mengeluarkannya dalam nisab tertentu (Mahfudh, 1994: xlix). Selama ini zakat dipahami sebagai aktivitas karitatif, melepaskan sebagian uang yang dimiliki seseorang untuk dimiliki ke orang lain. Selama ini pula, zakat dilakukan secara sukarela, sehingga apa yang diharapkan oleh zakat itu sendiri tidak tercapai. Walaupun, pada dasarnya agama dilaksanakan secara sukarela, ikhlas dan tidak dipaksa (Mas'udi dalam Rahmat, 2003: 100).

Menurut Jamal, realisasi dari fungsi zakat mengalami masalah yang disebabkan oleh: 1) pemahaman mayoritas yang masih melihat zakat sebagai 
ibadah ritual yang habis tanpa bekas; 2) kurangnya kesadaran masyarakat dalam menunaikan zakat; 3) minimnya profesionalisme amil zakat (Asmani, 2010: 94). Salah satu sebab belum berfungsinya zakat sebagai instrumen pemerataan dan belum terkumpulnya zakat secara optimal di lembagalembaga pengumpul zakat, karena pengetahuan masyarakat terhadap harta yang wajib dikeluarkan zakatnya masih terbatas pada sumber-sumber konvensional yang secara jelas dinyatakan dalam Alquran dan Hadis dengan persyaratan tertentu (Hafidhuddin, 2007: 2)

Selama ini, praktik penunaian zakat tidak jarang dilakukan dengan cara-cara konvensional (sendiri-sendiri) yang dalam praktiknya rentan bagi timbulnya persoalan. Kondisi ini diperparah dengan ketidakpahaman mengenai aturan dan pengelolaan zakat. Karenanya tidak jarang zakat yang seharusnya diperuntukkan bagi orang-orang yang berhak menerimanya, justru terjadi salah sasaran (Anshari, 2006: iv).

\section{Pengelola Zakat (Amil)}

Zakat sebagai rukun Islam merupakan kewajiban setiap muslim yang mampu membayarnya dan diperuntukkan bagi mereka yang berhak menerimanya. Dengan pengelolaan yang baik, zakat merupakan sumber dana potensial yang dapat dimanfaatkan untuk memajukan kesejahteraan umum bagi seluruh masyarakat. Agar sumber dana dapat bermanfaat bagi kesejahteraan masyarakat -terutama untuk mengentaskan kemiskinan dan menghilangkan kesenjangan sosial- perlu adanya pengelolaan zakat zecara profesional dan bertanggung-jawab yang dilakukan oleh masyarakat bersama pemerintah. Dalam hal ini pemerintah berkewajiban memberikan perlindungan, pembinaan, dan pelayanan kepada muzaki, mustahik, dan pengelola zakat (Sani, 2010: 8).

Dalam penyerahan zakat, ada beberapa cara yang ditempuh oleh umat Islam selama ini. Akan tetapi, pada kenyataannya penyerahan zakat kepada pihak-pihak pengelola zakat tersebut terdapat kelemahan-kelemahan yang menyebabkan sasaran yang disyariatkannya untuk menegakkan keadilan sosial dan kemaslahatan umat tidak tercapai. Pertama, di kalangan tradisional, pengelolaan zakat diserahkan kepada tokoh-tokoh keagamaan yang 
pentasarufannya memusat pada kebesaran nama tokoh tersebut. Kedua, pengelolaan zakat diserahkan kepada kalangan modernis (kaum pembaru) yang pentasarufannya lebih ditujukan untuk menjunjung tinggi ajaran yang memusat pada kebesaran nama organisasi dan aparat birokrasinya. Ketiga, pengelolaan zakat diserahkan pada Lembaga Swadaya Masyarakat (LSM). Pengelolaan zakat yang diserahkan kepada LSM ini pentasarufannya masih bersifat sekatarian atau kelompok tertentu (kelompok keagamaan). Selain itu LSM tidak memiliki kekuatan untuk mempengaruhi kebijakan publik dari negara mengenai kemiskinan dan ketidakadilan. Keempat, pengelolaan zakat diserahkan kepada lembaga yang bersifat semi-pemerintah, seperti Badan Amail Zakat (BAZ) dan Lembaga Amil Zakat (LAZ) di berbagai daerah di Indonesia.

Namun demikian, lembaga pengelola zakat ini memiliki beberapa kelemahan, di antaranya adalah: 1) Rendahnya kemampuan lembaga ini untuk mencapai sasaran sosial utama dari perintah zakat; 2) Lembaga ini tidak dapat memaksa mereka yang menolak membayar zakat dan tidak ada sanksi bagi mereka yang tidak menunaikan kewajiban membayar zakatnya padahal telah memenuhi syarat nisab. Keberadaan Undang-Undang Nomor 38 Tahun 1999 tentang pengelolaan zakat yang sudah berusia hampir 11 tahun belum mampu mengatasi permasalahan zakat, bahkan pengelolaan zakat bagai benang kusut yang tak terurai. Masyarakat menganggap hal itu disebabkan karena secara yuridis formal Undang-Undang ini hanya terbatas pada pengaturan pengelolaan zakat dan tidak memiliki kekuatan memaksa muzaki untuk membayar zakat; 3) Orientasi sosialnya masih bersifat sektarian; 4) Secara tidak disadari telah terjebak dalam kerangka pikir sekularistik yang memisahkan agama dan negara. Sehingga, posisi zakat seakan-akan terpisah dari negara. Agama memiliki dana zakatnya yang ada dalam kewenangan ulama, dan negara memiliki dana pajaknya yang ada dalam kewenangan umara (pemerintah). Pemahaman yang demikian menempatkan Tuhan, negara dan kehidupan sosial manusia pada tempat yang berbeda-beda, tidak saling terkait. Dalam agama Islam dikotomi seperti ini tidak bisa diterim, karena dalam Islam segala perbuatan lahiriah yang dilakukan manusia di dunia ini sebenarnya adalah juga merupakan bentuk perbuatan ruhaniah. Karenanya bisa dikatakan segala perbuatan lahiriah yang 
dilakukan merupakan bentuk ibadah. Ibarat ruh dan tubuh, yang keduanya tidak dapat dipisahkan satu dengan lainnya.

\section{Urgensi Negara sebagai Pengelola Zakat (Amil Zakat)}

Dengan menunjukkan beberapa kelemahan pihak lembaga pengelola (amil) zakat tersebut yang bisa mengakibatkan tidak tercapainya sasaran zakat, perlu ada solusi berupa sentralisasi pengelolaan zakat. Sentralisasi ini dikelola negara/pemerintah melalui lembaga resmi pemerintah yang memiliki hukum formal. Ini pula yang menjadi landasan pengelolaan zakat oleh pemerintah Malaysia, Brunei, Singapura, Kuwait, Mesir, Sudan dan Jordania, yang telah dikunjungi LAZ (Lembaga Amil Zakat) dan BAZ (Badan Amil Zakat) Nasional (Sani, 2010: 22).

Dikelolanya zakat oleh negara menjadikan zakat bukanlah sematamata urusan yang bersifat kedermawanan (charitative), tetapi juga bersifat otoritatif (perlu ada kekuatan yang memaksa). Contoh pelaksanaannya pada masa khalifah Abu Bakar dan Umar bin Abdul aziz. Pengelolaan zakat oleh lembaga pengelola zakat, apalagi memiliki kekuatan hukum formal, akan memiliki keuntungan, yaitu: 1) Menjamin kepastian dan disiplin pembayar zakat; 2) Menjaga perasaan rendah diri para mustahik zakat apabila berhadapan langsung untuk menerima zakat dari para muzaki; 3) Mencapai efisiensi dan efektivitas, serta sasaran yang tepat dalam penggunaan harta zakat menurut skala prioritas yang ada pada suatu tempat; 4) Memperlihatkan syiar Islam dalam semangat penyelenggaraan pemerintah yang islami. Sebaliknya, jika zakat diserahkan langsung dari muzaki kepada mustahik, meskipun secara hukum syariah adalah sah, tetapi akan terabaikan hal-hal tersebut di atas, juga hikmah dan fungsi zakat, terutama berkaitan dengan kesejahteraan umat (Hafidhuddin, 2008: 168-170).

Menurut Iskandar (dalam Sani, 2010), dengan dikelola negara, zakat menjadi kewajiban yang mengandung sanksi bagi pelanggarnya. Sebaliknya, kalau sekarang zakat baru berupa "pengurang penghasilan kena pajak", maka dengan amandemen UU Zakat bisa ditingkatkan menjadi "pengurang pajak" (tax deductable) sebagaimana di Malaysia. Selain memaksimalkan mobilisasinya, pengelolaan zakat oleh negara juga akan lebih efektif dan 
menasional, melalui fasilitas, sarana, prasarana, dan sumber daya yang menjangkau seluruh negeri dari sabang sampai Merauke (Sani, 2010: 220). Menurut Mas'udi, sebagai kewajiban sosial untuk cita keadilan dan kesejahteraan bersama, sudah barang tentu zakat (pajak) tidak akan ada yang mampu mengamili (memungut dan mengurusnya), kecuali pihak yang memiliki kewenangan formal untuk memaksa (forced power). Tanpa peranan "amil" yang demikian itu, suatu sedekah tidak bisa disebut zakat (pajak), tetapi hanya suatu charity atau kedermawanan belaka. Segi lain adalah bahwa negara/pemerintah adalah pihak yang paling layak untuk menangani zakat (pajak), karena adanya sasaran sosial dan kewajiban itu sendiri, yakni tegaknya keadilan sosial dan kesejahteraan umum. Sebagaimana diketahui, masalah keadilan dan kesejahteraan umum adalah persoalan struktural yang tidak mungkin terjangkau secara merata tanpa keterlibatan negara. Selain memiliki kewenangan formal yang mengikat, negara mampu menjangkau berbagai aspek kehidupan masyarakat dalam skala yang makro. Kualifikasi ini penting, lebih-lebih dalam tatanan masyarakat modern yang semakin terkait secara sistematik dan struktural antara satu unit sosial dan unit sosial yang lain.

\section{Prasyarat Negara}

Yusuf al-Qarḍāwi menyatakan bahwa zakat merupakan salah satu kiat menghapus kemisinan. Namun syaratnya, pengelola zakat menjadi bagian integral dari penerapan ajaran Islam secara kafah di segenap aspek kehidupan. Jadi bukan sekedar syariat tempelan pada sistem lain. Dan itu hanya mungkin berhasil jika dipraktikkan dalam masyarakat Islam yang berpegang teguh pada sistem Islam, baik dalam kehidupan ekonomi, sosial, maupun politik (Sani, 2010: 23).

Menurut Mas'udi, berkaitan dengan fungsi zakat (pajak) untuk keadilan dan kesejahteraan semua pihak, maka negara yang berhak mengelolanya adalah pemerintah yang lahir dari rakyat, dikontrol oleh suara rakyat, dan bekerja untuk kemaslahatan rakyat. Atau pemerintah yang sah lahirbatin untuk menangani zakat (pajak) adalah pemerintah yang adil, demokratis, dan berorientasi kerakyatan. Apabila dilihat dari kacamata Islam, pemerintah adalah penguasa yang kuat dan berwenang menuntut suatu hal 
terhadap rakyatnya. Di sisi lain ia juga merupakan "administrator" (amil) bagi kepentingan rakyat yang lemah. Oleh karena itu, tidaklah menjadi soal, apakah negara/pemerintah yang akan mengurus zakat itu harus negara agama, negara sekuler, atau yang berada di luar kedua kategori itu, seperti negara Republik Indonesia. Yang menjadi esensial bukanlah sebutannya, melainkan komitmennya pada tujuan disyariatkannya zakat/pajak itu, yakni redistribusi kekayaan untuk kemaslahatan dan keadilan bagi semua.

Evolusi Konsep Pajak

Pajak mempunyai peranan yang sangat penting -bisa disebut urat nadi- dalam penyelenggaraan negara, baik di negara yang menganut sistem demokrasi maupun otoriter. Artinya bahwa kelangsungan hidup suatu negara tergantung dari pajak yang dipungut dari rakyatnya. Apabila pajak dibayar, negara akan tegak. Sebaliknya apabila pajak diboikot, negara akan ambruk. Dimanapun dan pada zaman kapanpun, yang namanya negara (pemerintahan) selalu memungut dana wajib dari rakyatnya, pungutan yang dalam administrasi pemerintahan disebut pajak, atau tax dalam bahasa Inggris atau ḍaribah dalam bahasa Arab (Wahid, 2010: xx). Oleh sebab itu, visi dan bentuk negara akan sangat ditentukan oleh bagaimana urat nadi dan basis material negara yang bernama "pajak" itu diberi makna. Konsep yang difahami masyarakat seputar pajak di negaranya, akan sangat menentukan konsep negara yang dibangunnya (Mas'udi, 2010: 71).

Menurut Mannan (1984), jenis pajak pada masa khalifah menurut status kewarganegaraan, terbagi menjadi dua, yaitu pajak masyarakat Islam, yang dikenal juga dengan zakat, dan pajak untuk masyarakat nonmuslim, seperti jizyah (pajak kepala), kharāj (pajak tanah), ushur (pajak perdagangan). Ini bukan berarti adanya perbedaan pajak dalam sebuah negara Islam. Semua jenis pajak tersebut merupakan kewajiban masyarakat yang berdiam di negara Islam, baik muslim atau nonmuslim.

Menurut Mas'udi, sepanjang sejarah negara, pajak berkembang (berevolusi) melalui tiga konsep makna. Pertama, pajak dengan konsep "upeti" (daribah) atau persembahan kepada raja. Negara dengan pajak-upeti ini, adalah negara yang sepenuhnya tunduk pada kepentingan raja, atau elit penguasa. Pentasarufan dari pajak-upeti ini adalah sepenuhnya di tangan 
penguasa dan segenap kroni-kroninya yang serba mewah. Era upeti ini adalah era feodalisme raja-raja absolut. Di era ini belum dikenal adanya konsep korupsi sebagai kejahatan penguasa atau pejabat atas keuangan negara. Masyarakat masih menganggap sah semua penggunaan uang negara oleh penguasa.

Kedua, pajak dikonsepsikan sebagai "kontra-prestasi" (Alquran: Jizyah) atau imbal-jasa dari rakyat sebagai pembayar pajak kepada pihak penguasanya. Pajak boleh dipungut, tetapi negara/pemerintah harus membayar balik kepada rakyat berupa perlindungan dan pelayanan umum (public services) yang diperlukan. Negara dengan pajak-jizyah ini adalah negara yang mengabdi pada elit penguasa dan kelompok kaya. Kalangan kaya yang membayar pajak besar merasa berhak mendapatkan imbal-jasa kenegaraan yang besar, sebaliknya rakyat miskin yang tidak mampu membayar pajak harus menerima nasib untuk tidak dipedulikan oleh negara. Dalam era pajak-jizyah ini masyarakat mulai mengenal yang namanya kejahatan korupsi dan kolusi. Era ini adalah era abad modern kapitalistik dewasa ini, era demokrasi semu dan elitis, demokrasi pasar bebas tanpa nurani. Dan sepertinya, konsep pajak yang ada di Indonesia identik dengan jenis pajak yang pertama dan kedua ini, yakni masyarakat membayar pajak karena ada paksaan dari negara dan karena dilatarbelakangi sebagai imbal-jasa.

Akhirnya muncul konsep ketiga, pajak dengan konsep etik atau ruh zakat (pajak-zakat), yakni pajak sebagai sedekah karena Allah swt Sang Pencipta langit dan bumi, yang diamanatkan untuk kemaslahatan rakyat, terutama yang lemah, siapapun mereka, apa pun agama, etnis, ras, maupun golongannya. Anggapan bahwa jika pajak yang dibayarkan oleh warga negara Muslim dengan niat zakat hanya boleh diperuntukkan bagi umat Islam sama sekali tidak berdasar, sektarianistik, dan bertentangan dengan misi Islam untuk menjadi rahmat bagi semesta alam, sebagaimana pesan yang terdapat dalam QS. Al-Anbiya': 107 dan QS. Al-Taubah: 60 (Mas'udi, 2010: 204). Islam menyebut pajak dengan makna zakat yang secara harfiah berarti kesucian dan pertumbuhan. Artinya, dengan pajak sebagai zakat, kita menyucikan hati kita dari kedengkian dengan sesama, sekaligus mengembangkan kemakmuran dan keadilan untuk semua. Artinya, pajak bukan lagi sebagai persembahan (upeti) ataupun imbal jasa (jizyah) kepada 
penguasa, melainkan sebagai derma pembebasan untuk keadilan dan kemakmuran bagi semua, terutama mereka yang lemah (QS Al-Taubah: 60). Dari sini maka pajak akan dibayar dengan hati yang ikhlas sebagai bentuk kewajiban ilahiyah. Dalam konsep ini, setiap rupiah dari uang pajak adalah uang Allah yang diamanatkan kepada pejabat negara sebagai pelayan Allah dan rakyat (amil). Dalam konsep ini, bagi siapa saja yang menyalahgunakan uang pajak, tidak hanya sekadar harus mempertanggungjawabkannya secara sosial kepada rakyat (public accountability) saja, tetapi harus mempertanggungjawabkannya juga secara ruhaniah di akhirat kepada Allah swt. (spiritual \& moral accountability). Pajak dengan ruh zakat ini adalah konsep yang pernah diterapkan oleh Rasulullah saw. dan beberapa khalifahnya di Madinah 14 abad yang lalu sesuai dengan kondisi sosial dan material pada saat itu. (Mas'udi, 2010: 71)

\section{Implementasi Etika Zakat dalam Sistem Perpajakan}

Dalam rangka pencapaian tujuan etis zakat yakni keadilan sosial dan kemaslahatan rakyat terutama yang lemah, maka dalam pengelolaan pajak diperlukan seperangkat petunjuk pelaksanaan (juklak) yang sesuai dengan situasi dan kondisi di setiap masyarakat/negara. Petunjuk pelaksanaan (juklak) yang pernah disyariatkan Rasulullah saw. pada situasi dan kondisi di Madinah pada 14 abad yang silam, tidak bisa begitu saja dapat diterapkan untuk konteks hari ini dan di negara ini. Oleh karena itu pada dasarnya tidak ada aturan (syariah) yang bersifat mutlak untuk segala ruang dan waktu. Didalam Alquran ditegaskan:

"Untuk tiap-tiap umat di antara kamu, Kami berikan aturan dan jalan yang terang”.(QS Al-Ma'idah: 48)

Akan tetapi prinsip kontekstualitas yang jelas ini menjadi kabur dikarenakan pemahaman keagamaan kita yang dogmatis. Ini bukan berarti bahwa setiap ketentuan syariat harus diubah setiap saat disesuaikan dengan situasi dan kondisi yang terjadi. Dalam syariat ada unsur-unsur yang bersifat normatif (taklifi) dan yang bersifat konstitutif (waḍ'i). 
Sistem perpajakan untuk mencapai tujuan etiknya yakni keadilan dan kesejahteraan bagi semua, terutama yang lemah, dapat mencontoh model yang diterapkan Rasulullah saw. Rasulullah saw. selaku kepala negara/ pemerintahan mencanangkan sistem perpajakan yaitu: Pertama, berkaitan dengan batas minimal kekayaan/penghasilan kena pajak (nisab). Pajak-zakat merupakan kewajiban sosial yang harus dibayar oleh mereka yang telah memiliki tingkat kekayaan/penghasilan tertentu (nisab). Mereka yang belum mencapai nisab dibebaskan dari beban pajak, sebaliknya malah menjadi pihak utama yang berhak menerima (mustahik) bantuan negara dari dana pajak. Bagi yang telah mencapai nisab, kewajiban membayar pajak bisa dipaksakan oleh pihak yang diberi wewenang.

Kedua, berkaitan dengan objek pajak (māl zakawi). Pajak dikenakan atas jiwa (zakat fitrah) dan harta (zakat māl). Zakat māl dikenakan atas kekayaan dan penghasilan seseorang. Rasulullah saw. menetapkan jenis penghasilan dan kekayaan sebagai objek pajak yang sesuai dengan kondisi saat itu, meliputi hasil pertanian (zurū'), hasil kebun (thamar), ternak (mawāshy), niaga ('urūụ tijārah), hasil tambang (ma'din), harta temuan (rikāz, atau harta karun). Sedangkan kekayaan yang dikenakan pajak pada waktu itu adalah emas dan perak. Memang kalau kita kaitkan dengan konteks zaman sekarang ini yang lebih banyak sektor industri dan jasa, at uran teknis perpajakan pada masa Rasulullah saw. belum disinggung. Misalnya pada waktu itu belum ada kekayaan berupa kendaraan dan rumah mewah. Hasil niaga belum mencakup jual beli jasa keahlian atau profesi. Kategori ternak belum memasukkan seperti ternak unggas atau ikan tawar. Uang pun belum ada uang giral dan kertas berharga. Barang tambang juga belum termasuk minyak bumi, gas, timah, batu bara, dan sebagainya. Akan tetapi bukan berarti kalau Rasulullah saw. tidak membicarakannya lalu kekayaan-kekayaan tersebut harus bebas pajak (zakāh).

Ketiga, berkaitan dengan tarif pajak (miqdār). Tidak ada tarif pajak (miqdār zakah) yang dapat diberlakukan secara absolut untuk segala ruang dan zaman. Tarif pajak yang ditetapkan Rasulullah saw. adalah tarif yang relevan dan adil untuk masa itu. Tetapi dalam konteks kehidupan modern sekarang ini dimana tantangan keadilan dan kemaslahatan lebih berat, maka dapat ditentukan tarif pajak lain dan tarif pajak pada masa Rasulullah saw. dapat dijadikan sebagai tarif minimum. 
Keempat, berkaitan dengan kadar relatif dari tarif pajak. Dalam menentukan tarif pajak, Rasulullah saw. mempertimbangkan kondisi masyarakatnya. Misalnya Madinah -kawasan Arab- adalah negeri yang terbatas sumber alamnya, maka untuk kemakmuran penduduknya perdagangan menjadi andalan utama. Oleh karena itu Rasulullah saw. mengenakan tarif pajak yang rendah atas perdagangan, yang bertujuan agar sektor perdagangan tumbuh lebih pesat.

Kelima, berkaitan dengan waktu pembayaran pajak. Rasulullah saw. menetapkan bahwa sebagian pajak dibayar secara periodik. Misalnya niaga, industri, deposito, ternak, dan pajak jiwa. Sedangkan sebagian yang lain dibayarkan berdasarkan kapan penghasilan yang kena pajak itu diperoleh. Misalnya hasil pertanian, perkebunan, pertambangan, dan harta temuan.

Keenam, berkaitan dengan pengelola pajak (amil). Penunaian pajakzakat harus melewati pihak ketiga atau amil yang secara struktural memiliki kekuatan dan kewenangan. Pihak ketiga tersebut adalah imam atau pemerintah yang efektif dan memiliki komitmen terhadap kepentingan rakyat, terutama yang lemah, tanpa ada pilih kasih. Dilihat dari sisi struktural, dengan lembaga amil yang memiliki kewenangan formal ini, maka pihak yang menolak membayar pajak-zakat bisa dipaksa untuk menunaikan kewajibannya. Begitu juga dalam hal pentasarufan dapat berdampak nyata yaitu mewujudkan kehidupan sosial yang adil dan sejahtera bagi rakyat.

Dalam Alquran surat Al-Taubah ayat 60, Allah swt. berfirman: "Sesungguhnya zakat (pajak-pajak) itu hanyalah untuk orang-orang fakir, orang-orang miskin, amilin, para mualaf, untuk (memerdekakan) budak, orang-orang yang berutang, untuk jalan Allah, dan ibn sabil, sebagai sesuatu ketetapan yang diwajibkan Allah. Dan Allah Maha Mengetahui lagi Maha bijaksana” (QS. Al-Taubah: 60).

Surat Al-Taubah ayat 60 ini merupakan acuan moral bagi penyusunan Anggaran Belanja Negara, dan juga merupakan acuan moral bagi kinerja seluruh institusi negara. Sasaran-sasaran alokasi anggaran negara seperti yang disebut dalam ayat tersebut dapat dikelompokkan ke dalam tiga sektor besar, yaitu:

1) Sektor pemberdayaan masyarakat yang lemah, meliputi: fuqarā', masākīn, mu'allaf qulūbuhum, riqāa, ghārimīn, dan ibn sabīl. 
2) Sektor biaya rutin pemerintahan ('ämilin)

3) Sektor sabìilillāh atau layanan publik, baik yang bersifat fisik, seperti pembangunan jalan, pengairan, konservasi alam, dan lain-lain, maupun yang bersifat nonfisik seperti penegakan hukum, pengembangan ilmu pengetahuan dan kebuadayaan.

\section{Lembaga Amil Pajak-Zakat}

Untuk mencapai tujuan etis pajak-zakat yaitu keadilan dan kesejahteraan rakyat, terutama yang lemah, maka yang layak dan mampu mengamili (mengurus dan memungut) zakat (pajak) adalah pihak yang memiliki kewenangan formal untuk memaksa (forced power) yaitu negara atau pemerintah. Negara bisa memaksa orang-orang kaya yang pelit untuk membayarkan kewajiban sosialnya. Siapa saja yang menolak menunaikannya, maka bisa dikenakan sanksi yang membuatnya jera. Negara juga berfungsi sebagai tumpuan untuk tegaknya keadilan sosial dan kesejahteraan umum, karena negara mampu menjangkau berbagai aspek kehidupan masyarakat yang lebih luas atau dalam skala makro. Akan tetapi, tentunya negara yang berhak untuk mengelola dana zakat (pajak) adalah negara/pemerintah yang lahir dari rakyat, dijalankan atas mandat rakyat, dikontrol oleh suara rakyat, dan bekerja untuk kemaslahatan rakyat. Tidak peduli apakah bentuk negara/ pemerintahan yang akan mengurus zakat (pajak) itu adalah negara agama, negara sekuler ataupun yang berada di luar kedua kategori itu, seperti negara Republik Indonesia. Di sini yang terpenting adalah bahwa negera/ pemerintahan itu memiliki komitmen pada tujuan disyariatkannya zakat/ pajak, yaitu redistribusi kekayaan untuk kemaslahatan dan keadilan untuk semua masyarakat.

Dari sudut syariat, dengan membayar zakat (pajak) kepada pemerintah, meskipun masih terdapat penyimpangan dalam pentasarufannya, kewajibannya sudah dianggap gugur, alias terpenuhi. Sebagaimana tersirat dalam konsepnya tentang zakat Rasulullah saw. (seolah) berkata: "Niatkan karena Tuhan (demi tegaknya cita kerakyatan dan keadilan) apa yang kalian serahkan kepada negara". Dalam hadis mutawatir, Nabi mengatakan, "Sesungguhnya (makna) suatu amal perbuatan itu tergantung/ditentukan 
oleh niatnya”. Niat adalah ruh, persambungannya dengan Tuhan. Sedangkan amal, seperti sedekah atau bayar pajak, adalah badan, persambungannya dengan manusia. Keduanya berbeda, akan tetapi tidak bisa dipisahkan apalagi dipertentangkan. Keduanya harus disatukan sebagaimana menyatunya ruh dengan badan. Oleh sebab itu, uang pajak secara lahiriah memang diserahkan kepada negara sebagai pelembagaan kepentingan manusia dalam mengatur kehidupannya. Adapun untuk Tuhan, adalah niat yang menjiwai dan melatarbelakangi penyerahan uang pajak itu saja.

\section{Hubungan Islam dan Negara}

Ada tiga pandangan menyangkut agama dan negara. Pertama, pandangan yang mewajibkan pendirian sebuah negara Islam. Kedua, pandangan tentang negara sekuler, dimana penganut paham ini meyakini bahwa urusan negara bukanlah urusan agama sehingga urusan negara tidak ada campur tangan agama. Ketiga, pentingnya internalisasi nilai-nilai Islam dalam bernegara tanpa harus melabeli dengan nama negara Islam. Menurut penganut paham ini, hubungan agama dan negara bagaikan dua mata sisi uang. Konsep negara ini dalam praktiknya kombinasi kepentingan dengan nilai-nilai Islam tanpa harus menyematkan nama negara Islam, tetapi juga tidak menjadi negara sekuler (Pranowo, 2011: vii).

Mohammad Natsir (dalam Kamaruzzaman) menegaskan bahwa negara hanyalah sebagai alat. Karena sebagai alat, maka Islam sebagai dasar negara telah tercakup di dalamnya. Artinya, integrasi antara Islam dan negara adalah saling mengisi satu sama lain. Dengan kata lain, Islam hanya menyediakan perangkat dasar, sedangkan untuk implementasinya adalah dengan cara berijtihad (Kamaruzzaman, 2001: 94).

Hubungan antara Islam (agama) dan negara bukan merupakan hubungan antara dua institusi kekuasaan (power institution) yang terpisah satu dengan lainnya seperti yang selama ini dipahami mengacu pada hubungan dualistik antara gereja dan negara di Barat. Agama (gereja) berada di bawah negara seperti zaman Romawi klasik, atau Agama (gereja) di atas negara seperti pada abad pertengahan, atau gereja dan negara duduk berdampingan di wilayah kewenangannya masing-masing seperti pada abad 
sekarang ini. Tetapi, hubungan Islam (agama) dan negara adalah diibaratkan seperti hubungan antara jiwa dan raga, antara ruh dan badan, antara nilai dan institusi, atau antara visi dan aksi. Artinya, Islam (agama) dan negara memang berbeda, tetapi tidak boleh dipisahkan; agama memberi arah, negara memberi bentuk. Bagi umat Islam, agama adalah pesan keadilan universal untuk semua warga, terutama yang lemah (Mas'udi, 2010: 165-166).

Dengan demikian, manunggalnya kembali pajak dan zakat, membawa implikasinya sendiri atas pemahaman kita mengenai konsep hubungan agama dan negara. Dalam kerangka penafsiran itu, agama tidak lagi dipandang sebagai entitas kelembagaan yang terpisah dari negara. Seperti halnya zakat sebagai spirit yang merasuk ke dalam pajak sebagai badan. Demikian pula agama, ia adalah spirit, ruh ilahiyat, yang harus merasuki dan membimbing arah dan jalannya negara sebagai sosok badaniah dan kelembagaan yang profan. Dengan demikian, konsep zakat sebagai spirit pajak tidak lain adalah juga sebuah konsep spiritualisasi dan transendentalisasi kehidupan negara itu sendiri. Dan yang dimaksud agama sebagai spirit negara adalah keruhanian universal yang bersifat inklusif, yakni komitmen pada keadilan semesta terutama bagi mereka yang lemah dan terpinggirkan. Siapapun mereka, dan apa pun agama dan keyakinan mereka (Wahid, 2010: xxii).

\section{Beberapa Pendapat Mengenai Pajak dan Zakat}

Perdebatan dan perbedaan pendapat di kalangan masyarakat tentang persamaan dan perbedaan antara pajak dengan zakat masih terus berkembang sampai saat ini. Sebagian kalangan ada yang mempersamakan secara mutlak antara pajak dan zakat dan sebagian yang lain membedakannya secara mutlak antara keduanya. Dalam bab ini mengemukakan beberapa pendapat mengenai persamaan dan perbedaan antara pajak dan zakat. Sebelum mengetahui persamaan dan perbedaan antara pajak dan zakat, terlebih dahulu perlu diketahui definisi dari pajak dan zakat.

Menurut Undang-Undang Nomor 28 Tahun 2007, definisi pajak adalah kontribusi wajib kepada negara yang terutang oleh orang pribadi atau badan yang bersifat memaksa berdasarkan Undang-Undang, dengan tidak mendapatkan imbalan secara langsung dan digunakan untuk keperluan negara bagi sebesar-besarnya kemakmuran rakyat. 
Menurut Gazi Inayah (dalam Gusfahmi), pajak adalah kewajiban untuk membayar tunai yang ditentukan oleh pemerintah atau pejabat yang berwenang yang bersifat mengikat tanpa adanya imbalan tertentu. Ketentuan pemerintah ini sesuai dengan kemampuan si pemilik harta dan dialokasikan untuk mencukupi kebutuhan pangan secara umum dan untuk memenuhi tuntutan politik keuangan bagi pemerintah (Gusfahmi, 2007: 31).

Pajak adalah kewajiban yang ditetapkan terhadap Wajib Pajak, yang harus disetorkan kepada negara, sesuai dengan ketentuan, tanpa mendapat prestasi kembali dari negara. Adapun hasilnya adalah untuk membiayai pengeluaran-pengeluaran umum di satu pihak dan untuk merealisasikan sebagian tujuan ekonomi, politik, sosial dan tujuan-tujuan lain yang ingin dicapai oleh negara.

Adapun zakat menurut ahli fikih, ialah hak tertentu yang diwajibkan Allah swt. terhadap harta kaum muslim yang diperuntukkan bagi mereka, yang dalam Alquran disebut -kalangan fakir miskin, dan mustahik lainnyasebagai tanda syukur atas nikmat Allah swt. dan untuk mendekatkan diri kepada-Nya, serta untuk membersihkan diri dan hartanya (Al-Qarḍāwi, 1991: 999).

Dari definisi tersebut, menurut Yusuf al-Qarḍ̄āwi titik persamaan antara pajak dan zakat adalah terdapat pada: a) Segi unsur paksaan dan kewajiban, b) Harus disetorkan kepada lembaga negara (pemerintah) selaku amil zakat, d) Tidak adanya imbalan tertentu (langsung) bagi Wajib Pajak dan Zakat, e) Tujuan yang sama, baik kemasyarakatan, ekonomi, politik maupun keuangan. Sedangkan perbedaannya adalah terdapat pada: a) Dari segi nama dan etiketnya, b) Mengenai hakikat dan tujuan, artinya pajak adalah kewajiban negara dan zakat adalah kewajiban agama, c) Mengenai batas nisab dan ketentuannya, d) Mengenai kelestarian dan kelangsungannya, e) Mengenai pengeluarannya/pentasarufannya f) Hubungannya dengan penguasa g) Maksud dan tujuan, zakat memiliki tujuan spiritual dan moral yang lebih tinggi dari pajak (Al-Qarḍāwi, 1991: 999-1005).

Menurut Didin Hafidhuddin, persamaan antara zakat dan pajak adalah terletak pada: a) Unsur paksaan, b) Unsur pengelola, c) Dari sisi tujuan. Sedangkan perbedaaanya terletak pada: a) Segi nama, b) Segi dasar hukum dan sifat kewajiban, c) Segi objek dan persentase dan pemanfaatan 
(Hafidhuddin, 2007: 52-58). Menurut Abdul Ghafur Anshari, persamaan antara pajak dan zakat adalah keduanya sama-sama merupakan kewajiban yang dibebankan kepada warga negara untuk kemaslahatan umat. Sedangkan perbedaannya adalah pada: a) Segi bahasa, b) Segi pengaturan, c) Segi objeknya, d) Segi haul, e) Segi niatan dan peruntukan (Anshari, 2006: 180-185).

Sedangkan menurut Gusfahmi dalam bukunya Pajak Menurut Syariah (2007: 221), persamaan dan perbedaan zakat dengan pajak menurut syariah Islam, dapat dilihat dalam tabel berikut:

\begin{tabular}{|c|c|c|}
\hline Uraian & Pajak & Zakat \\
\hline Dasar hukum & $\begin{array}{l}\text { Undang-Undang negara } \\
\text { yang mengacu kepada } \\
\text { Alquran dan Hadis }\end{array}$ & $\begin{array}{l}\text { Undang-Undang negara } \\
\text { yang mengacu kepada } \\
\text { Alquran dan Hadis }\end{array}$ \\
\hline Subjek & Pribadi muslim & Pribadi muslim \\
\hline Objek & $\begin{array}{l}\text { Kelebihan penghasilan, } \\
\text { konsumsi barang bukan } \\
\text { kebutuhan pokok }\end{array}$ & $\begin{array}{l}\text { Harta tertentu yang melebihi } \\
\text { nisab }\end{array}$ \\
\hline Sifat & Kewajiban keagamaan & Kewajiban keagamaan \\
\hline Syarat ijab kabul & Tidak diisyaratkan & Disyaratkan \\
\hline $\begin{array}{l}\text { Masa berlaku } \\
\text { kewajiban }\end{array}$ & $\begin{array}{l}\text { Temporer atau situasional } \\
\text { (tidak sepanjang masa) }\end{array}$ & $\begin{array}{l}\text { Sepanjang masa walaupun } \\
\text { tidak ada fakir miskin }\end{array}$ \\
\hline Jumlah terutang & $\begin{array}{l}\text { Maksimum sesuai yang } \\
\text { ditetapkan }\end{array}$ & $\begin{array}{l}\text { Minimum sejumlah yang } \\
\text { ditetapkan }\end{array}$ \\
\hline Penggunaan dana & $\begin{array}{l}\text { Pengeluaran negara selain } \\
\text { mustahik zakat }\end{array}$ & Mustahik tertentu \\
\hline Imbalannya & $\begin{array}{l}\text { Tersedianya barang dan jasa } \\
\text { untuk masyarakat }\end{array}$ & Pahala dari Allah swt. \\
\hline Tarif & $\begin{array}{l}\text { Ditetapkan berdasarkan } \\
\text { ijtihad ulama }\end{array}$ & $\begin{array}{l}\text { Ditetapkan berdasarkan } \\
\text { Alquran dan Hadis }\end{array}$ \\
\hline $\begin{array}{l}\text { Penentu kegunaan } \\
\text { dana }\end{array}$ & $\begin{array}{l}\text { Pemerintah dengan } \\
\text { berdasarkan syariat }\end{array}$ & $\begin{array}{l}\text { Allah swt, harus sesuai } \\
\text { dengan } a s ̦ n \bar{a} f \text { yang } 8\end{array}$ \\
\hline Penerima manfaat & $\begin{array}{l}\text { Semua golongan, termasuk } \\
\text { orang kaya }\end{array}$ & Aṣ nā $f 8$ \\
\hline $\begin{array}{l}\text { Tujuan } \\
\text { perolehannya }\end{array}$ & $\begin{array}{l}\text { Untuk kepentingan } \\
\text { kemaslahatan umat, yang } \\
\text { tidak terpenuhi dari zakat }\end{array}$ & $\begin{array}{l}\text { Untuk mencegah } \\
\text { ketidakwajaran dan ketidak- } \\
\text { seimbangan distribusi } \\
\text { kekayaan }\end{array}$ \\
\hline Saat terutang & Saat diperoleh & $\begin{array}{l}\text { Setelah satu tahun kecuali } \\
\text { zakat pertanian }\end{array}$ \\
\hline Fungsi & Solusi untuk kondisi darurat & Bagian keimanan atas harta \\
\hline
\end{tabular}

Berdasarkan pendapat-pendapat yang diuraikan di atas menunjukkan bahwa antara pajak dan zakat tidak sama secara mutlak. Pada sisi tertentu 
pajak dan zakat terdapat persamaan. Di sisi lain terdapat perbedaan yang mendasar di antara keduanya. Hal ini berbeda dengan apa yang telah disampaikan oleh Mas'udi dalam bukunya ini.

\section{Upaya Mensinergikan Kewajiban Zakat dan Pajak di Indonesia}

Indonesia adalah negara yang mayoritas penduduknya beragama Islam, tetapi Indonesia bukan negara Islam. Di negara ini pajak dan zakat telah terpolarisasi sedemikian rupa. Seolah-olah ada dikotomi di antara keduanya. Pajak merupakan wilayah negara dan zakat berada di wilayah agama. Zakat difahami semata-mata hanya sebagai perintah dan misi keagamaan. Sedangkan pajak adalah perintah dan urusan negara, urusan dunia yang tidak ada sangkut pautnya dengan keagamaan.

Akibat polarisasi atau dikotomi antara pajak dan zakat tersebut, seorang muslim yang bertempat tinggal di Indonesia memiliki dua identitas yakni, sebagai seorang muslim dan seorang warga negara Indonesia. Oleh karena itu seorang muslim di Indonesia mempunyai dua kewajiban yang harus ditunaikan, kewajiban pertama adalah membayar pajak sebagai realisasi menunaikan kewajiban kepada negara dan kewajiban kedua adalah membayar zakat sebagai realisasi menunaikan kewajiban agama. Warga negara Indonesia yang beragama Islam masih tetap wajib membayar zakat walaupun mereka telah membayar pajak.

Permasalahan seperti itulah yang terjadi di Provinsi Nangroe Aceh Darussalam (NAD). Di propinsi itu diberlakukan atau mempunyai dua jenis pungutan wajib: Pertama, Undang-undang mengenai kewajiban pajak penghasilan diatur dalam Undang-Undang Nomor 17 tahun 2000 yang diamandemen menjadi Undang-Undang Nomor 36 Tahun 2008 pasal 21; Kedua, kewajiban zakat yang terdapat pada Qanun (peraturan daerah) No 7 Tahun 2004 Provinsi NAD. Karenanya, timbullah permasalahan, yaitu umat Islam di sana diwajibkan untuk membayar kedua jenis pungutan pada waktu yang sama (zakat dan pajak). Ini merupakan beban yang harus dipikul oleh seorang individu muslim yang berada di Propinsi NAD.

Penetapan UU No. 8 tahun 1999 tentang Pengelolaan Zakat, dan UU Nomor 17 tahun 2000 tentang Pajak Penghasilan dapat dipandang 
sebagai langkah maju menuju sinergi zakat dengan pajak. Menurut Abdul Ghafur Anshari, upaya sinergis yang dimaksud adalah: Pertama, UU No 38 Tahun 1999 telah mengakui, bahwa sesungguhnya zakat adalah kewajiban yang harus ditunaikan oleh setiap muslim warga negara Indonesia yang mampu. UU ini memang tidak menyebutkan hukuman bagi yang melanggar kewajiban zakat, tetapi setidaknya pemerintah telah secara eksplisit bertanggung-jawab memberikan perlindungan, pembinaan dan pelayanan kepada Muzaki, mustahik dan Amil zakat. Kedua, pemerintah telah melibatkan diri lebih jauh dalam pengelolaan zakat dengan membentuk BAZ dan LAZ di berbagai tingkat kewilayahan dari kecamatan hingga nasional. Ketiga, seperti disebutkan dalam UU No 38/1999 bahwa zakat yang telah dibayarkan kepada BAZ atau LAZ akan dikurangkan terhadap laba/penghasilan sisa kena pajak dari wajib pajak yang bersangkutan.

Namun, sayangnya perlu disadari bahwa sesungguhnya antara UU No. 17 Tahun 2000 dan UU No. 38 Tahun 1999 tidaklah konsisten. Misalnya, dalam UU No. 17 Tahun 2000 dinyatakan bahwa yang dapat dikurangkan atas penghasilan kena pajak hanyalah zakat penghasilan (zakat profesi). Sementara, di dalam UU No. 38 Tahun 1999 disebutkan bahwa zakat (tanpa embel-embel atas penghasilan) dapat dikurangkan atas penghasilan kena pajak.

Hal lain yang patut disayangkan adalah bahwa UUPZ tidak menetapkan sanksi yang seimbang antara pengelola dan muzaki. Idealnya, sanksi hukum tidak hanya dikenakan kepada pengelola zakat saja, tapi juga kepada muzaki yang tidak melaksanakan kewajibannya (Anshari, 2006:186-188).

\section{Penutup}

Buku ini merupakan sebuah bentuk ijtihad yang dilakukan oleh Mas'udi mengenai permasalahan-permasalahan kontemporer melalui pendekatan Islami, dalam hal ini zakat. Zakat merupakan salah satu instrumen penting yang dianggap mampu untuk menegakkan keadilan sosial dan kemaslahatan rakyat terutama bagi yang lemah. Penafsiran zakat sebagai konsep perpajakan yang disampaikan oleh Mas'udi dalam buku ini bisa dipastikan banyak mengundang reaksi dari kalangan masyarakat antara yang 
pro dan kontra. Banyak yang menganggap pemikiran tersebut telah keluar dari koridor hukum Islam yang telah lama dijadikan pegangan.

Terlepas dari pro dan kontra terhadap pemikiran Mas'udi tersebut, terdapat pesan penting yang perlu kita cermati dari tulisan Mas'udi yaitu ketika kita membayar pajak dengan niat zakat (sedekah karena Allah swt), maka pajak yang telah kita bayarkan sudah menjadi zakat dan kita berhak mendapatkan pahalanya (zakat). Niat kita dalam membayar pajak akan menentukan nasib negara ini. Dengan niat berzakat pada waktu membayar pajak maka berarti kita memiliki andil bagi terwujudnya negara ini menjadi negara yang penuh keadilan dan kesejahteraan dan terhindar dari segala bentuk kezaliman.

Akhirnya, pembahasan dan penggarapan isu-isu kontemporer yang berkembang dengan pendekatan keagamaan dan menggunakan Islam sebagai bingkai perspektifnya, masih terbuka lebar bagi siapa saja yang ingin berijtihad mencurahkan pemikirannya baik secara sendiri-sendiri maupun ijtihad kelompok. Itu sebagai bentuk kepedulian dan perhatian yang besar terhadap harapan Islam, yakni keadilan sosial dan kemaslahatan umat (rakyat).

\section{Daftar Pustaka}

Al-Qarḍāwi, Yusuf. 1991. Hukum Zakat. Jakarta. Pustaka Litera Antarnusa. Anshari, Abdul Ghafur. 2006. Hukum dan Pemberdayaan Zakat: Upaya Sinergis Wajib Zakat dan Pajak di Indonesia. Yogyakarta. Pilar Media Anwar Sani, M. 2010. Jurus Menghimpun Fulus: Manajemen Zakat Berbasis Masjid. Jakarta. Gramedia

Asmani, Jamal Ma'mur. 2010. 13 Cara Nyata Mengubah Takdir. Jakarta. Wahyu Media.

Azra, Azyumardi. 2007. Jejak-jejak Jaringan Kaum Muslim dari Australia Hingga Timur Tengah. Bandung: Mizan.

Mas’udi, Masdar Farid. 14 April 2011. Uang Pajak dalam Perspektif Islam. Republika online.

1992. Zakat dan Pajak: Jawaban Masdar Farid Mas'udi kepada Kyai Kholil Bisri Rembang. Jakarta. Aula.

Gusfahmi SE MA. 2007. Pajak Menurut Syari'ah. Jakarta. PT Raja Grafindo Persada. 
Hafidhuddin, Didin. 2007. Zakat dalam Perekonomian Modern. Jakarta. Gema Insani

Hafidhuddin, Didin. 2008. Agar Harta Berkah dan Bertambah: Gerakan membudayakan Zakat, Infak, Sedekah dan Wakaf. Jakarta. Gema Insani

Kahf, Monzer. The Principle of Socioeconomics Justice in The Comtemporarry Fiqh of Zakah. Iqtisad. Journal of Islamic Economics. Vo. 1. Muharram $1420 \mathrm{H} /$ April 1999.

Kamaruzzaman. 2001. Relasi Islam dan Negara. Magelang. IndonesiaTera.

Mahfudh, Sahal. 1994. Nuansa Fiqih Sosial. Yogyakarta. LKis.

Mannan, M.A (1984) Islamic Economic Theory and Practice Lahore Muhammad Ashraf

Media, Pilar. 2006. "Pengantar Redaksi" dalam buku Hukum dan Pemberdayaan Zakat: Upaya Sinergis Wajib Zakat dan Pajak di Indonesia. Yogyakarta. Pilar Media

Pranowo, Bambang. "Kata Pengantar" dalam buku Chiefdom Madinah: Salah Faham Negara Islam. Jakarta. Pustaka Alvabet, 2011.

Rahmat, Imdaddun. 2003. Islam Pribumi: Mendialogkan Agama. Jakarta. Erlangga

Sari, Elsi Kartika. 2007. Pengantar Hukum Zakat dan Wakaf. Jakarta: Grasindo

Siddik, Abdullah. 1993. Inti Dasar Hukum Dagang Islam. Jakarta. Balai Pustaka

Syarbini, Muhammad. Al-Iqna'fi Halli Al-Fadhi Abi Syuja', Daru Ihya AlKutub, Indonesia

Sembilan, Tim. 2004. Tafsir Maudhu'i Al-Muntaha. Yogyakarta. Pustaka Pesantren.

Taher, Tarmidzi. 2002. Menyegarkan Akidah Tauhid Insani Mati di Era Klenik. Jakarta. Gema Insani Press.

Wahid, Abdurrahman. 2010. "kata pengantar" dalam buku Pajak itu zakat: uang Allah untuk kemaslahatan rakyat. Bandung. Mizan

Yasid, Abu. 2004. Islam Akomodatif, Rekonstruksi Pemahaman Islam sebagai Agama Universal. Yogyakarta. LKiS. 